\title{
Can brain impermeable BACE1 inhibitors serve as anti-CAA medicine?
}

\author{
Jian-Ming Li ${ }^{1,2}$, Li-Ling Huang $^{3}$, Fei Liư ${ }^{4}$, Bei-Sha Tang ${ }^{1}$ and Xiao-Xin Yan ${ }^{1,3^{*}}$
}

\begin{abstract}
Background: Cerebral amyloid angiopathy (CAA) is characterized by the deposition of $ß$-amyloid peptides (Aß) in and surrounding the wall of microvasculature in the central nervous system, together with parenchymal amyloid plaques collectively referred to as cerebral amyloidosis, which occurs in the brain commonly among the elderly and more frequently in patients with Alzheimer's disease (AD). CAA is associated with vascular injury and may cause devastating neurological outcomes. No therapeutic approach is available for this lesion to date.

Main body: $B$-Secretase 1 (BACE1) is the enzyme initiating Aß production. Brain permeable BACE1 inhibitors targeting primarily at the parenchymal plaque pathology are currently evaluated in clinical trials. This article presents findings in support of a role of BACE1 elevation in the development of CAA, in addition to plaque pathogenesis. The rationale, feasibility, benefit and strategic issues for developing BACE1 inhibitors against CAA are discussed. Brain impermeable compounds are considered preferable as they might exhibit sufficient anti-CAA efficacy without causing significant neuronal/synaptic side effects.
\end{abstract}

Conclusion: Early pharmacological intervention to the pathogenesis of CAA is expected to provide significant protection for cerebral vascular health and hence brain health. Brain impermeable BACE1 inhibitors should be optimized and tested as potential anti-CAA therapeutics.

Keywords: Alzheimer's disease, B -Amyloid, Cerebral amyloidosis, Neurodegeneration, Vascular dementia

\section{Background}

Cerebral amyloid angiopathy (CAA) refers to $ß$-amyloid $(A ß)$ deposition in and surrounding the wall of cerebral vasculature, often involving small to mid-sized arteries, and less commonly capillaries and veins. $A ß$ deposition along the leptomeninge is also considered a part of CAA [1-5]. Aging and Alzheimer Disease (AD) appear to be the major risk factors for CAA. Epidemiological studies suggest that $10 \%$ to $40 \%$ of the elderly have CAA, with the frequency raised up to $80 \%$ among patients with $\mathrm{AD}$ [6]. The incidence of moderate to severe CAA ranks approximately $2.3 \%, 8 \%$ and $12.1 \%$ among individuals at $65-74,75-84$ and over 85 years of age, respectively $[1,7]$. Compared to non-demented individuals, the morbidity and severity of CAA both appear to be

\footnotetext{
* Correspondence: yanxiaoxin@csu.edu.cn

${ }^{1}$ Department of Neurology \& Key Laboratory of Hunan Province in

Neurodegenerative Disorders, Xiangya Hospital, Central South University,

Changsha, Hunan 410008, China

${ }^{3}$ Department of Anatomy and Neurobiology, Central South University School

of Basic Medical Science, Changsha, Hunan 410013, China

Full list of author information is available at the end of the article
}

increased in demented or AD subjects. Thus, although CAA may be considered as a sign of brain aging, it could be related to the development and progression of dementia of the AD and vascular types [8-14].

While CAA is considered as a pathological change than disease entity, its clinical implication has gained growing attention in the medical field. CAA appears to be one of the most common reasons for primary, nontraumatic and non-hypertensive cerebral haemorrhage $[4,5,10,15]$. Elderly with mild CAA in their brains might exhibit no neurological symptoms. With the progress of CAA, more damage and breakdown of the blood-brain barrier (BBB) and vascular wall can occur, raising the risk of suffering from overt clinical symptoms possibly as a result of silent but substantial intracranial haemorrhage and ischemic neuronal stress and injury $[10,13,16-18]$. Unfortunately, there are no preventive or therapeutical approaches available for CAA to date [19].

Brain imaging technologies are advancing quickly and can nowadays detect signs of CAA at preclinical stages 
[20-22], providing potential screening guide for early pharmacological intervention to the lesion among at-risk individuals. Progress in basic and pathological research has been also made in understanding of the pathogenesis of CAA. Specifically, recent studies have extended evidence in support of an involvement of BACE1 elevation in CAA pathogenesis [23-25], in addition to amyloid plaque formation. This raises an opportunity of using BACE1 inhibition as a therapeutic, perhaps even preventive, option to delay or slow-down the development of CAA and thus mitigate its destructive neurological consequences. While BACE1 inhibition is being vigorously explored in clinical trials as an anti-Aß therapy primarily targeting at the parenchymal plaque lesions, there is less discussion about its potential for the treatment of CAA. In this review, we first briefly introduce the biochemical aspects of $A ß$ genesis and clearance, and the cellular expression of $A ß$-producing proteins in the brain including vasculature, with a preference given to update BACE1-related data. We then address the pathological and pathogenic aspects of CAA, focusing on recent findings about the role of BACE1-mediated $A ß$ overproduction. Finally we discuss the benefit, feasibility and some strategic issues for developing BACE1 inhibitors primarily targeting at CAA, in addition the compounds designated to reduce amyloid plaque lesions explored currently in clinical trials. Given the interconnecting nature of CAA with parenchymal amyloidosis, issues related to the amyloid plaque pathology and its intervention are also covered briefly while addressing the above topics.

\section{Main text}

Biochemical perspectives of $A ß$ production and clearance $ß$-Amyloid peptides are derived from the $B$-amyloid precursor protein (APP), which is an integral membrane protein ubiquitously expressed in cells of the body including neurons [26-28]. APP can interact with many adaptor proteins and bind to some extracellular matrix components including heparin and collagen, as such serving a crucial role in cell-cell communication and intracellular signalling. APP may be involved in broad biological functions in the body, including hormonal regulation [29] and iron export [30], and in the nervous system, participates in neuronal development, signal transduction, axonal transport, synaptic formation and repair [31-37].

Biochemically, APP is cleaved by the so-called secretases, and by some other proteolytic enzymes as well, yielding many forms of fragment products [38-42]. The secretasemediated cleavages include the non-amyloidogenic and amyloidogenic pathways. The former is executed by $\alpha-$ secretase and $\gamma$-secretase complex, likely as the predominant form of APP processing under physiological condition.
The amyloidogenic pathway is initiated with $\beta$-site cleavage of APP by BACE1, releasing $\beta$-site cleaved $C$-terminal fragments $(\beta-C T F s)$, which are further cut by $\gamma$-secretase to produce Aß [43-47]. Depending on the sites of $\gamma$-cutting, $A ß$ may contain amino acid (a.a.) residues of varying lengths [48]. The $A ß$ mono-peptides could bind together to form soluble oligomers, and insoluble aggregates that deposit as microscopically evident extracellular lesions in the brain. A new $\eta$-secretase APP processing pathway initiated by some membrane-bound matrix metalloproteinases has been identified lately, which may lead to the formation of long and short An peptides as end products following $\alpha$ - and $\beta$-secretase proteolyses [49].

Besides regulation at the level of production, several clearance mechanisms help maintain the concentration of $A B$ in the brain homeostatically. Thus, it is suggested that $A ß$ products are removed from the brain through (1) being endocytosed by astrocytes and microglia; (2) being degraded by some enzymes including neprilysin and the insulin-degrading enzyme; (3) being cleared from brain parenchyma into blood after passing through BBB; (4) being drained out of the brain through the periarterial spaces via some specific routes, for instance, along intracortical microvascular walls to leptomeningeal arterial walls, and finally to cranial and cervical lymph nodes [50-53].

\section{Cellular localization of Aß-producing proteins in the brain including vasculature}

Many original studies and reviews have described the cellular expression pattern of the Aß-producing machinery, i.e., APP, BACE1 and subunit proteins of the $\gamma$-secretase complex, in mammalian brains e.g., $[54,55]$, therefore we only shortly note this issue here. Overall, neurons appear to be the major cell type in the brain with enriched expression of APP and BACE1, as well as presenilins (PS1 and PS2) that serve as the catalytic core of $\gamma$-secretase complex. Previous studies have shown distinct immunolabeling of APP and PS1/PS2 in the somata and dendrites of neurons in mammalian brains [56-58]. Immunolabeling of BACE1 has been detected in neurons and glial cells [59], while some antibodies label a pattern with predominant reactivity in the neuropil, particularly distinct at some brain areas rich of synaptic terminals, i.e., the olfactory bulb glomeruli and hippocampal mossy fibres [60-64]. The notion that presynaptic terminals as an important site of $A ß$ production is supported by increasing cell biology, biochemical and anatomical data [65-71]. Specifically regarding synaptic function and plasticity, BACE1 is shown to be dynamically transported in axons via antegrade and retrograde trafficking $[65,66]$. Moreover, APP cleavages can occur directly in synaptic vesicles, with $A ß$ produced at and released by presynaptic axon terminals [67-71]. 
Apart from neurons, many studies have demonstrated that the cellular components of blood vessels possess the biochemical machinery for $A ß$ production. At the messenger level, vascular endothelial cells express three alternatively spiced APP mRNA isoforms, APP695, APP751 and APP770, in comparison with neurons that appear to only or predominantly express APP695 [72]. In cell culture studies, brain microvascular endothelial cells and human umbilical vein endothelial cells are found to express APP, BACE1 and PS1 by immunoblot and immunocytochemical analyses, and can secret $A ß$ into culture medium detectable by ELISA [73-77]. Similar results are obtained from experiments using primary cell cultures prepared from surgically removed human blood vessels [25]. Some studies have also shown that cultured vascular smooth muscle cells express APP, BACE1 and PS1 [23, 78, 79]. Notably, in histological preparations of animal or human brains without amyloid pathology, the cerebral blood vessels or their cellular components (i.e., endothelial and smooth muscle cells) generally do not exhibit impressive immunolabeling of APP, BACE1 or PS1, relative to the immunoreactivity seen in neuronal elements $[56,57,60-62,80]$. Thus, the overall levels of expression of the Aß producing proteins in vascular cells are apparently lower relative to neurons in normal animal or human brain.

\section{Pathological characteristics of CAA}

As with the amyloid plaque lesions, CAA can occur broadly in the central nervous system including the spinal cord [1-7, 81]. In comparison, little information indicates the existence of parenchymal and angiopathic types of $A ß$ deposition in the periphery [82]. Such an organ/tissue preference of $ß$-amyloidosis appears to suggest some root link of the lesions to specific cellular components of the nervous system. Overall, cortical and leptomeningeal arteries appear to be mostly susceptible to $C A A$, while $A ß$ deposition could occur at veins and venules. The neocortical vessels appear to be firstly and most frequently affected, followed by that in the paleocortex and midbrain. Less involved areas include the basal nuclei, dorsal thalamus and brainstem [1-8, 83-85].

The onset and progression of CAA at a given vascular site are still not well understood to date. Pathological observations suggest that at arterioles $A ß$ products may first deposit in the basement membrane of the tunica intima, then accumulate in the smooth muscle layer or the tunica media. The smooth muscle cell layer may be eventually destroyed and replaced by $A ß$ fibrils, which could mount progressively to become very heavy to a point until no cellular components in this layer left [86]. Notably, perivascular Aß deposition can occur along with the lesion inside the vascular wall. The profiles with concurrent vascular and perivascular $A ß$ deposition have been defined as "dysphoric" or "dyshoric" CAA [86-89]. We observed fairly frequent perivascular $A ß$ deposition at cerebral vasculature with either mild or severe amyloidosis inside the wall or the smooth muscle cell layer in postmortem human brains [25] (Fig. 1a-c). Some perivascular $A ß$ deposition exhibited the morphological configuration of diffuse or compact plaques (Fig. 1d-g). When comparing cortical arterioles with varying extent of $A ß$ deposition, a pattern of pathological evolution appeared to exist. Thus, $A ß$ immunolabeling appeared to occur initially at the tunica intima, followed by the tunica media and perivascular zone. In some arterioles and capillaries, the tunica intima or endothelial cells exhibited extremely heavy $A ß$ immunolabeling (Fig. 2a-f).

\section{Role of $A ß$ overproduction in parenchymal plaque amyloidosis}

The pathogenic mechanism underlying cerebral amyloidosis as either parenchymal plaques or CAA is still not consensually defined, with the lesions collectively regarded as resulted from an imbalance between the production and clearance of the $A ß$ peptides. It is suggested that a global rise of $A ß$ levels in the interstitial fluid of the brain triggers self-propelling aggregation of the peptides to form insoluble products. According to the original amyloid hypothesis [90], reduced $A B$ clearance from the brain is the principal or primary causal factor for cerebral amyloidosis in sporadic AD. Among the $A ß$ clearance mechanisms as noted above, the blocking of perivascular drainage is considered a crucial one. It is also suggested that $A ß 42$ tends to precipitate in brain interstitial space to form senile plaques, whereas Aß40 has a better solubility, therefore more likely to be drained away through the perivascular space and thus deposit preferentially at cerebral vessels as CAA [16]. Increased peripheral $A ß$ transit across the blood brain barrier (BBB) and "back-flushing" into the brain is also hypothesized [91-97]. Of note, recent studies have shown that reducing periphery $A ß$ does not apparently alter brain amyloidosis or $A ß$ levels in the cerebrospinal fluid [98-100]. Increased $A ß 42 / A ß 40$ ratio [16, 100-103] and prion-like propagation [104-107] are also suggested to promote cerebral amyloidosis. Overall, an unifying hypothesis remains to be established to coherently explain as to why $A ß$ deposition manifests in different patterns, occurs at selected locations and develops site-specifically in the human brain.

Data are also collected pointing to a role of localized $A ß$ overproduction in cerebral plaque formation. Increased BACE1 expression and activity are reported in the brains from individuals with sporadic AD [108-116]. To address the issue as to whether BACE1 elevation may occur in spatial relevance with parenchymal $A B$ 

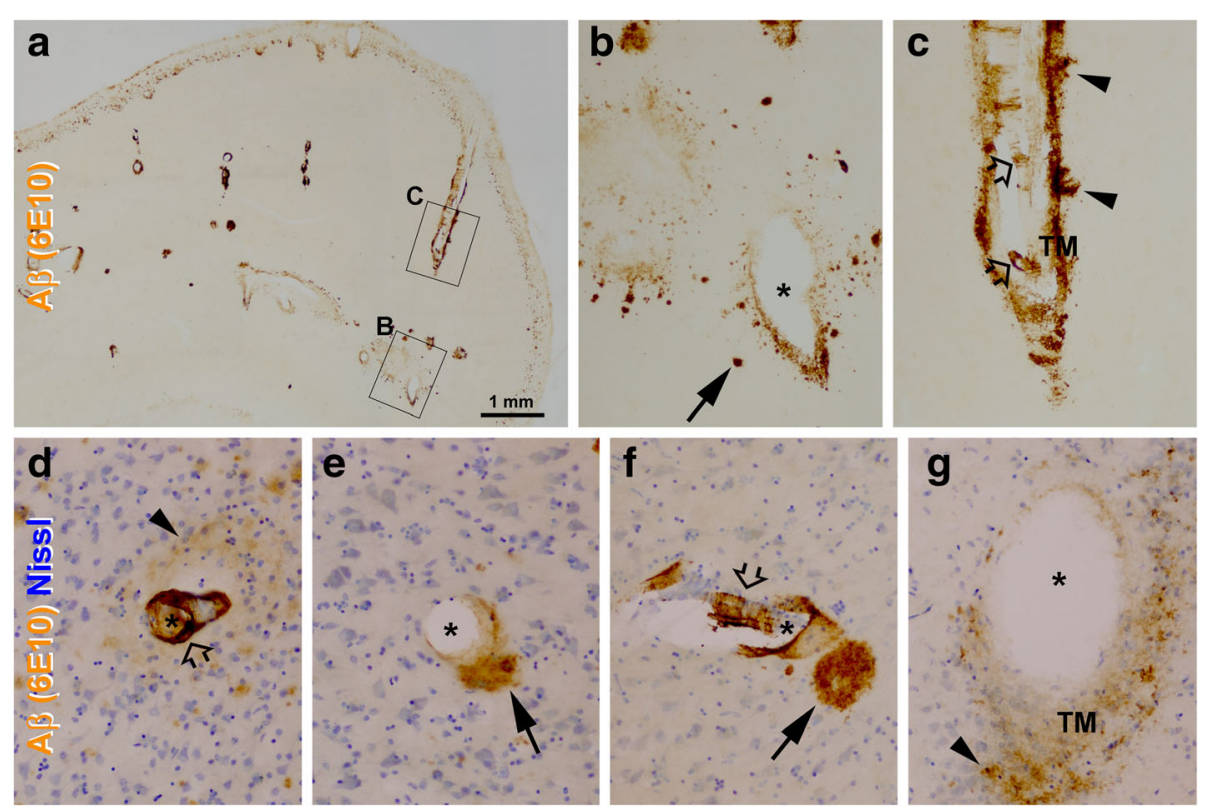

Fig. 1 Microscopic images showing examples of cerebral amyloid angiopathy (CAA) from aged human brain. Panel (a) is a low magnification view of $\beta$-amyloid (AB) immunolabeling with the monoclonal antibody 6 E10 obtained from the temporal neocortex. Meningeal amyloid labeling is present along the cortical surface, with labelled individual arterioles of varying sizes invading and inside the cortex. Punctuate immunoreactive profiles occur along the low portion of layer I. Panels (b) and (c) are enlarged views of the framed areas in (a). Panels $(\mathbf{d}-\mathbf{g})$ are high power views of 6E10 immunolabeling with Nissl counterstain. Note the presence of perivascular amyloid deposition (pointed by arrows and arrowheads) in addition to the labeling in the wall of affected vessels, which appear diffuse (arrowheads) or compact (arrows) like in morphological pattern. Both large (c) and small (d, $\mathbf{f}$ ) vessels can exhibit heavy immunolabeling at the inner layer of the vascular wall (open arrows). * : vascular cavity. Scale bar $=1 \mathrm{~mm}$ in (a), equal to $200 \mu \mathrm{m}$ for other panels. Images are adapted from original data of recent studies [25, 162]

deposition, several groups used well-characterized BACE1 antibodies for comparative analysis of BACE1 and $A ß$ immunolabeling in the brains of transgenic AD mouse models, aged humans and clinically diagnosed AD subjects, and aged nonhuman primates [62, 80, 113-116]. These studies have consistently demonstrated increased BACE1 expression in swollen/ sprouting axonal terminals, commonly referred to as the dystrophic neurites, in neuritic plaques.

Whether chronic/persistent BACE1 elevation in association with an ongoing neuritic pathogenesis plays a principal role in plaque formation in the human brain remains to be established. The amounts of BACE1 labelled dystrophic neurites do not always match to the extent of amyloidosis anatomically and densitometrically in postmortem human brains, with $A ß$ deposition appeared much denser relative to neuritic profiles especially among the cases with advanced $\mathrm{AD}$ pathologies [80]. However, one can argue that the two measurements should not match to each other for several reasons. First, $A ß$ immunolabeling seen in the sections would most likely represent the amount of insoluble deposits accumulated over time, while BACE1 immunolabeling would more likely reflect the amount of the enzyme present at the cross-sectional time point when the brain is processed. Second, insoluble Aß deposits are known to resistant to postmortem tissue/protein degradation. In fact, amyloid pathology can been detected in human brains collected months even years after death [117-119]. On the other hand, histological integrity and biological molecules including normal neural proteins are decomposed rapidly if brain samples are not preserved by tissue fixation on time [117]. Moreover, dystrophic neurites of the amyloid plaques show high structural plasticity over time [120], and $A ß$ production as a biochemical process is depended on the viability of the dystrophic neurites [121]. With the build up of $A ß$ deposits, viable cellular elements including dystrophic neurites may be dying out because of the so-called "burn-out" effect [122, 123].

For the other type of parenchymal plaques, the diffuse plaques, it has been difficult to determine if BACE1 elevation in local cellular elements is involved. When examining human brain samples, no distinct profiles with enhanced BACE1 immunolabeling are detectable over the areas with diffuse amyloid deposition (own experience). This is also the case for the fairly distinct $A ß$ labeling along the low portion of cortical layer I as seen in some human brains (as shown in Fig. 1a for example). Layer I is innervated richly by axonal terminals from some subcortical structures, including the monoaminergic projections from the brainstem [124, 125]. These fine axonal terminals also distribute along the wall 

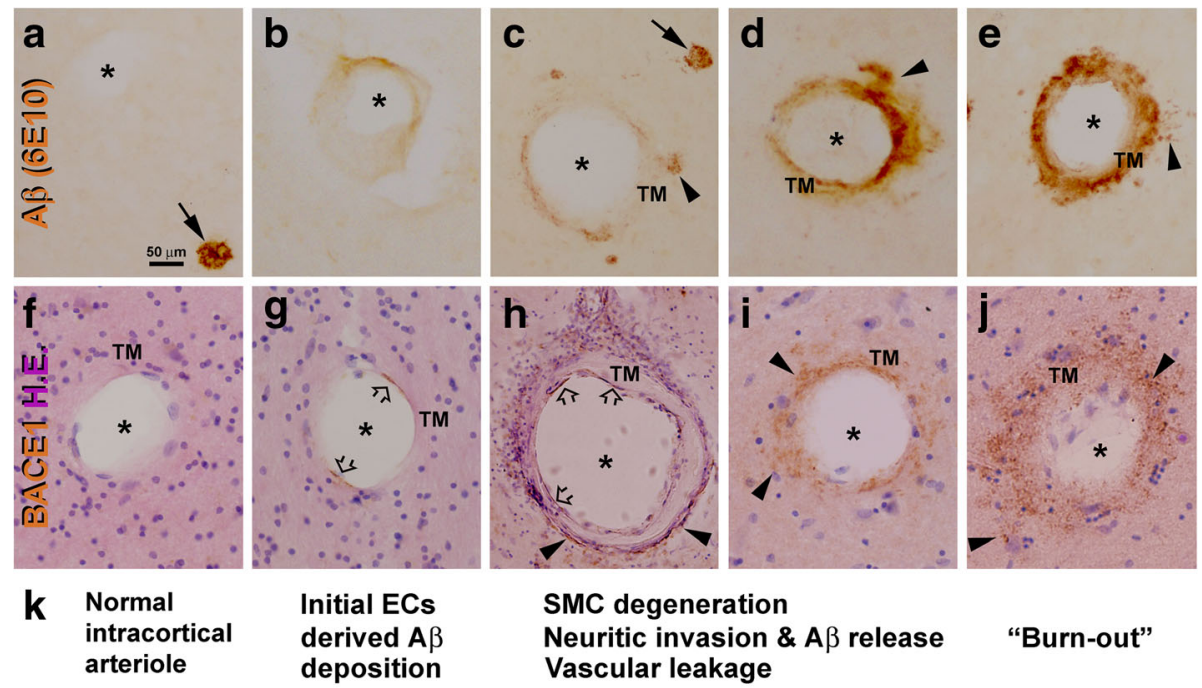

SMC degeneration

Neuritic invasion \& $A \beta$ release

"Burn-out" Vascular leakage
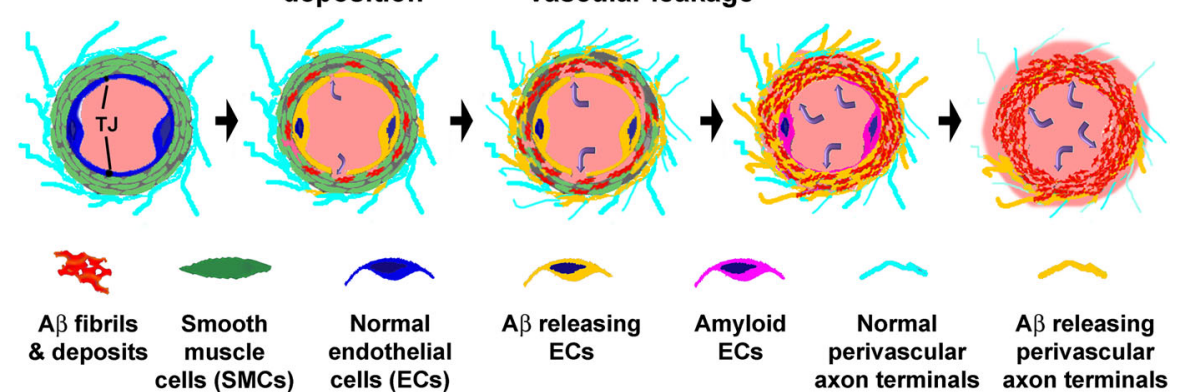

Fig. 2 Microscopic images and schematic drawings illustrating a hypothetic model of cerebral amyloid angiopathy. Panels (a-f) show arterioles without (a) and with $\beta$-amyloid labeling of increasing intensity. A $\beta$ deposition appears to occur around the tunica intima or endothelial layer $(\mathbf{b}, \mathbf{c})$, then emerges and accumulates in the tunica media (TM) (c-f). Perivascular deposition (arrowheads) is seen around vessels with mild to severe $A \beta$ labeling in the vascular wall (c-f). Panels (f-j) are images of $\beta$-secretase 1 (BACE1) immunolabeling with $\mathbf{h} . \mathbf{e}$. counterstain, showing arterioles without $(\mathbf{f})$ and with immunolabeled elements exhibiting a progressive pattern $(\mathbf{g}-\mathbf{j})$. Thus, BACE1 labeling is identifiable at the endothelial layer in $(\mathbf{g}, \mathbf{h})$, occurs at the perivascular zone in $(\mathbf{h})$ and presents across the vascular wall and perivascular zone in $(\mathbf{i}, \mathbf{j})$. Arrows point to compact plaques. Scale bar $=50 \mu \mathrm{m}$ in $(\mathbf{a})$ applying to $(\mathbf{b}-\mathbf{g}, \mathbf{i}, \mathbf{j})$, equal to $100 \mu \mathrm{m}$ for $(\mathbf{h})$. Panel (k) illustrates a hypothetic model for BACE1 elevation in vascular and brain-specific cellular elements in the development of CAA. BACE1 elevation first occurs in endothelial cells (ECs), resulting in AB accumulation in the smooth muscle cell (SMC) layer. This causes damage of tight junctions (TJ) and leakage of blood contents into the SMC layer (curved arrows). A $\beta$ and blood infiltration then induce SMC degeneration, triggering aberrant sprouting of the perivascular axonal terminals inherent neuronal $A \beta$ overproduction. This process continues progressively and may end up with a "burnout" stage whereby the ECs, SMCs and dystrophic neurites all degenerate. This figure is adapted with modification from Fig. 7 in [25]

of pial arteries invading into the cortex, serving a key role in coupling neuronal activity and blood supply. Notably, in examination of perfusion-fixed brains from some transgenic mouse models of $\mathrm{AD}$, e.g., the $3 \times \mathrm{Tg}-\mathrm{AD}$ mice, increased BACE1 immunolabeling at fine axonal profiles are clearly present over the areas with diffuse $A ß$ deposition in the forebrain [126].

In the human or transgenic AD mouse brains wherein the neuropathology is well established, it is difficult to determine the causal relationship between axonal dystrophy and $A ß$ deposition as one attempts to address the issue of onset and development of the neuritic plaques. A dynamic interplay between the two would likely exist, resulting in a feed-forward vicious cycle in the course of plaque pathogenesis [55, 66, 117]. Notably, in wild-type animals wherein no elevated $A ß$ levels are pre-existed in the brain, many experimental insults, such as traumatic brain injury [127-130], microvascular embolism [131], pilocarpine-induced temporal lobe epilepsy [132] and endotoxin-induced neuroinflammation [133], can clearly induce a dystrophic axonal pathology inherent with APP/BACE1 upregulation in the affected brain regions, although extracellular $A ß$ deposition may not be detectable. When such experimental insults are applied to transgenic AD models, they could accelerate the agerelated development of neuritic plaque pathogenesis in the brain [134-136].

\section{Role of $A B$ overproduction in cerebral angiopathic amyloidosis}

Many groups of investigators have carried out in vitro and in vivo experiments to explore a potential involvement 
of $A ß$ overproduction in the development of CAA [23-25, 73-78]. Specifically, an active role for BACE1mediated $A ß$ overproduction in vascular endothelial cells has been proposed for angiopathic amyloidosis [23-25]. We examined the spatial relationship between BACE1 expression and CAA in postmortem human brains, with particular attention paid to understand the cellular components potentially exhibiting increased BACE1 immunolabeling around amyloid vasculature [25]. There appeared to exist a comparable pattern between $A ß$ and BACE1 immunolabeling in and surrounding the wall of cortical arterioles (Fig. 2a-j). Enhanced BACE1 immunolabeling around the tunica intima appeared to occur in the endothelial cells (Fig. 2g, h). BACE1 immunoreactive profiles were also found in the tunica media and the perivascular regions, identified as neuronal processes rather than smooth muscle cells, neurons or glial cells (Fig. 2h-j). These BACE1 labelled profiles represented sprouting axonal profiles given their colocalization with synaptophysin, and nicotinamide adenine dinucleotide phosphatediaphorase (NADPH-d) that is expressed in the processes of nitric oxide (NO) producing interneurons [137]. Based on these observations, we proposed a dual-origin model for angiopathic $A ß$ deposition in the human brain [25] (Fig. 2k). Thus, vascular endothelial cells begin to overexpress BACE1 (likely APP as well) and increase Aß production in response to certain circulatory stress factors. The $A ß$ products are released into blood (hence cleared away) as well as inside the vascular wall, with the latter retained and deposited locally causing some initial damage of the tight junction between endothelial cells. The accumulation of $A ß$ together with infiltration of blood (potentially containing inflammatory factors) resulted from $\mathrm{BBB}$ leakage into the vascular wall causes stress/damage and degeneration of the smooth muscle cells. Cellular toxicities from $A ß$ and other inflammatory molecules as well as a space-emptying effect in the smooth muscle cell layer may trigger a regenerative response of the perivascular axonal terminals, manifested by aberrant sprouting into and surrounding the vascular wall. Because the axonal pathology is inherent with BACE1/APP overexpression, a second wave of increased local $A ß$ production occurs and mounts $A ß$ products on-site. This neuronal contribution of $A B$ could continue until some point whereby all viable cellular components (vascular cells and dystrophic neurites) become degenerated ("burn-out"), leaving the original vascular site as an end-pathology locus heavily filled with $\mathrm{A} ß$ fibrils. This dual-origin hypothesis could explain as to why CAA can occur in and surrounding the wall of cerebral arterioles, capillaries and venules, although the latter two have no or only a thin small muscle cell layer. It can also help understand as to why amyloid angiopathy is observed in the central nervous system yet rarely (if any) in the peripheral organs. It should be noted that the leptomeningeal amyloidosis might also develop via a dual or triple origin mechanism, such that vascular endothelia, perivascular axonal processes and the meningeal cells participate in $A ß$ overproduction resulting in spreading amyloidosis along the cortical surface [25] (Fig. 1a).

Considering endothelia as an early CAA contributors, it would be important to explore if some circulatory factors may promote the amyloidogenic response of these cells. Epidemiological studies suggest that many cardiovascular and metabolic conditions are risk factors for dementia of the vascular and AD types, including hypertension, hypotension, hypercholesterolemia, atherosclerosis and diabetes [138-143]. In vitro studies have demonstrated that oxygen and glucose deprivation [75], proinflammatory cytokines [77] and high cholesterol [144] may serve as stress factors to stimulate endothelial $A ß$ production possibly via BACE1 upregulation. The endothelial nitric oxide synthase (eNOS) could participate in modulating the amyloidogenic processing pathway in vascular endothelia [74].

\section{Brief update on BACE1 inhibitors targeting against the amyloid plaque pathology}

The anti-Aß approach for the treatment of AD has been vigorously pursued in the past two decades. Overall, most drug candidates based on active and passive $A \beta$ immunization, anti- $A ß$ aggregation and $\gamma$-secretase inhibition have failed in clinical trials. BACE1 inhibition has been left as a highly expected anti-Aß option, although the final outcome of ongoing drug trials remains uncertain. In-depth reviews on the anti-Aß therapies for $\mathrm{AD}$ treatment/prevention are available, with some works focused on the BACE1 inhibition strategy specifically [54, 55, 145-152]. To avoid redundancy, we will only denote on a few issues here as the following.

Sufficient target engagement to neuronal BACE1 has been much concerned in the development of BACE1 inhibitors to minimize plaque pathology. As the catalytic core of the enzyme is relatively wide, early generations of BACE1 inhibitory compounds are too large to have sufficient brain penetration [149, 151]. With chemical modification of lead compounds, brain permeable BACE1 inhibitors have been successfully developed, with several front-running candidates in the pipeline entered clinical trials. LY2886721 is the first reached Phase II trail, which was discontinued due to potential liver toxicity (https://investor.lilly.com/releaseDetail.cfm?Release ID=771353). Verubecestat represents the latest BACE1 inhibitor with initial clinical trial data reported. This compound has excellent safety and target engagement profiles according to phases I and II trials, but has been also terminated in phase III trials among patients with mild to moderate $\mathrm{AD}$ at the time of subject registration, due to a lack of efficacy in slowing down cognitive decline 
(http://www.businessinsider.com/r-acceras-alzheimers-trialfails-in-yet-another-setback-for-disease-2017-2). Currently, stage III trials on Verubecestat are continued in patients with early or prodromal stage $\mathrm{AD}$, which might soon provide crucial assessment for the therapeutic efficacy of $\mathrm{BACE} 1$ inhibition (or anti-A $\beta$ therapy in general) for $\mathrm{AD}$.

However, potential side-effects of long-term BACE1 inhibition are a concern for the currently explored brain penetrant compounds. While initial data from BACE1 knockout mice suggest that BACE inhibition may not cause serious neurological side effects [54], it is now known that BACE1 plays critical biological roles in the central and peripheral nervous systems, including for axon growth and myelination, neuronal and glial genesis, ion channel activity and neuronal excitability [146, 148, 150-154]. Thus, BACE1 deficiency might cause impairment of physiological neuronal and synaptic functions. In fact, BACE1 null mice exhibit some neurological and cognitive deficits [60]. They also show malformation of the olfactory bulb glomeruli and axonal mis-targeting in the hippocampal mossy fiber pathway [60, 61, 63, 64]. More recent studies indicate that pharmacological inhibition of BACE1 with brain penetrant compounds can cause neuronal and synaptic deficits. For instance, prolonged treatment with the inhibitor SCH1682496 or LY2811376 can lead to reduced spine formation of layer $\mathrm{V}$ pyramidal neurons in adult mice. The rate of spontaneous and miniature excitatory postsynaptic currents in pyramidal neurons and hippocampal long-term potentiation are also reduced in the drug-treated animals. Moreover, cognitive deficits are observed in behavioural tests in these animals [155]. Overall, a relatively long period of evaluation would be needed to assure the safety of the brain penetrating BACE1 inhibitors.

\section{Benefit, feasibility and strategy for developing anti-CAA BACE1 inhibitors}

As denoted in the preceding sections, CAA is associated with structural damage of the BBB and the entire vascular wall that can impair the regulated blood supply to brain parenchyma. Vascular leakage and micro-bleeding may also directly cause stress and damage to neuronal structures around the lesion [1-15]. Importantly, microvascular damage has been suggested to potentiate some neurodegenerative changes in $\mathrm{AD}$, including the development of neuritic plaques because they are distributed in close proximity to capillaries $[80,88,89,131,156-160]$. Given the direct and indirect contribution of CAA to neuronal dysfunction and cognitive impairments during aging and in dementia of the vascular or AD type, therapeutic approaches to prevent or halt this pathology should be considered and pursued. Because CAA involves essentially the microvasculature, pharmacological intervention is likely the only solution. Although the development of CAA may have many upstream etiological factors, Aß accumulation and deposition are the core event or a final crossroad of the condition. Interrupting at this crucial step of CAA development appears to be well justified theoretically.

The experimental data suggesting a key role of BACE1 upregulation in the pathogenesis of CAA by mediating $A ß$ overproduction in local cellular components, as assembled in our dual-origin hypothesis (Fig. 2k), highlight the feasibility for using BACE1 inhibitors as putative anti-CAA therapeutics. Vascular endothelia participate in the initial step of $A ß$ overproduction, therefore confronting this alteration by BACE1 inhibition could provide early protection. Inhibiting endothelial BACE1 activity can be expected to reduce the release of $A B$ into the smooth muscle layer of arterioles and venules, therefore protect the integrity of vascular wall, and stop/delay vascular leakage and microhemorrhages. This would minimize the stress to perivascular neuronal processes and their reactive sprouting into and surrounding the vascular wall in association with neuronal $A ß$ overproduction. In capillaries, BACE1 inhibition in endothelial cells may prevent these cells from becoming amyloid, and also prevent the pericapillary neuronal processes from undergoing amyloidogenic axonal pathology. In the case that a certain degree of CAA and vascular damage have already taken place, BACE1 inhibitors might get access into the smooth muscle cell layer and the perivascular zone, and target on neuronal BACE1 overexpression in the sprouting axonal processes. Thus, BACE1 inhibitors may be expected to target-engage with the cellular elements involved in the early as well as ongoing phases of $A B$ overproduction during the development of CAA.

In the pharmaceutical industry, there are examples that opportunity and success of drug discovery arise from initially unspeculated therapeutic target or effect of the candidate drugs (as was the case of Viagra). As mentioned earlier, during the development of BACE1 inhibitors many lead compounds are discarded from further translational evaluation because they are not brain penetrant to target neuronal BACE1 [149]. The discussions elaborated above would imply that brain impermeable inhibitors could otherwise serve as desired anti-CAA drug candidates. Without passing through the $\mathrm{BBB}$, they may inhibit BACE1 activity in vascular endothelia therefore provide the first line protection against amyloid damage to blood vessels [24]. They may also diffuse into the vascular wall or to some extent the perivascular area in the case that some BBB breakdown has already occurred, which could still reduce the $A ß$ genesis in the smooth muscle cell layer, brought in by the invading perivascular neuronal processes. In this regard, it is of 
interest to note that typical neuritic plaques are anatomically vasocentric since they occurs preferentially next to capillaries [80, 130, 156-158]. In addition, cellular and molecular components of blood are detected in neuritic plaques, suggestive of the existence of vascular leakage [159-165]. Thus, while brain impermeable BACE1 inhibitors are expected to primarily act against CAA, theoretically they can also diffuse across the damaged capillary wall and inhibit amyloidogenesis in the dystrophic neurites of neuritic plaques therefore mitigate this parenchymal amyloid pathology.

As aforementioned, BACE1 plays critical physiological roles in normal neuronal/synaptic structures $[60,61$, 63-71, 150-152]. Thus, perhaps the most significant advantage of brain impermeable BACE1 inhibitors over permeable ones is that the former may not elicit much unwanted effect to neurons and synapses in healthy brain regions and structures. Thus, this type of inhibitors might be used chronically as preventive as well as therapeutic regiments. Taken together, brain impermeable BACE1 inhibitors can be expected to have a better target engagement, relative to permeable ones, to act more selectively on the cellular elements exhibiting pathologically enhanced BACE1 activity (i.e., vascular cells and perivascular dystrophic neurites around CAA as well as neuritic plaques). Re-evaluation of some brain impermeable BACE1 inhibitory lead compounds and further development of this class as anti-Aß reagents primarily targeting at CAA but potentially at parenchymal plaques as well, are worth pursuing.

Strategic issues for the development of anti-CAA BACE1 inhibitors also include a more thorough understanding of the biological role of the enzyme in vascular endothelia. So far, no data have shown significant malformation or dysfunction of the cardiovascular system in BACE1 knockout mice (to the best of our knowledge). However, comprehensive in vitro and in vivo investigations would still be needed to firmly confirm that pharmacological inhibition of endothelial BACE1 does not impair vascular health in the central and peripheral systems. Since clinical trials on existing brain permeable BACE1 inhibitors are ongoing and the outcomes could be available in the near future, brain imaging and pathological information about CAA is worth collecting from the subjects participated in the trials. These inhibitors might also have some effect on the vascular cellular components, thus, in addition to the measurements of parenchymal amyloidosis and cognitive performance, clues of improvement on CAA pathology are worth searching from available postmortem brains of the enrolled subjects, even in the case that the cognitive outcomes obtained during the period of clinical trial are not excellent.

\section{Conclusions}

Cerebral vascular health is crucial for brain health in humans. As one of most common brain angiopathic lesions, CAA is associated with vascular deficits but may cause direct and indirect neuronal injury leading to devastating neurological outcomes, therefore playing an unneglectable role for cognitive decline during "normal" brain aging and in $\mathrm{AD}$. CAA has been long regarded as to occur following some primary vascular deficit causing a passive retention of $A ß$ at the brain-blood interface. The findings assembled in this review from original studies point to an active role of increased $A ß$ production by local cellular elements, primarily the endothelial cells and perivascular neuronal terminals, in the pathogenesis of CAA. Such findings encourage the development of active pharmacological approaches to confront the development of CAA. BACE1 is the key enzyme for $A ß$ production. Brain penetrant BACE1 inhibitors are being tested in clinical trials to mitigate plaque development for $\mathrm{AD}$ therapy. We propose here brain impermeable BACE1 inhibitors as putative therapeutics to mitigate CAA, which may offer desirable efficacy to prevent vascular amyloidosis yet avoid unwanted side effects duo to inhibition of neuronal and synaptic BACE1 activity in normal brain regions and structures. Attenuating CAA pathogenesis could stabilize vascular integrity and functionality, and improve overall brain health among the elderly at risk of suffering from dementia of the vascular as well as $\mathrm{AD}$ types.

\section{Abbreviations}

AD: Alzheimer's disease; APP: B-Amyloid precursor protein; AB: B-amyloid peptides; BACE1: 3 -secretase-1; BBB: Blood brain barrier; CAA: Cerebral amyloid angiopathy; eNOS: Endothelial nitric oxide synthase; PS: Presenilin; $\beta$-CTFs: B-Cterminal fragments

\section{Acknowledgements}

None.

\section{Funding}

The original studies helped the assembly of this work were supported by the National Natural Science Foundation of China (NNSFC) (\#31371095 and \#91632116 to X.X. Yan). J.M. Li is supported by China Postdoctoral Research Foundation (\#2016 M590757) and Hunan Family Planning \& Health Commission (\#B2017041). The funding bodies are not involved in the design of the study and collection, analysis, and interpretation of data.

\section{Availability of data and materials}

This review work does not contain original data to be shared.

\section{Authors' contributions}

JML and LLH: Figure assembly and manuscript drafting. FL, BST and XXY: Formulated the idea and finalized the manuscript. All authors read and approved the final manuscript.

Ethics approval and consent to participate Not applicable.

Consent for publication Not applicable. 


\section{Competing interests}

The authors declare that they have no competing interests.

\section{Publisher's Note}

Springer Nature remains neutral with regard to jurisdictional claims in published maps and institutional affiliations.

\section{Author details}

'Department of Neurology \& Key Laboratory of Hunan Province in Neurodegenerative Disorders, Xiangya Hospital, Central South University, Changsha, Hunan 410008, China. ${ }^{2}$ Neuroscience Research Center, Changsha Medical University, Changsha, Hunan 410219, China. ${ }^{3}$ Department of Anatomy and Neurobiology, Central South University School of Basic Medical Science, Changsha, Hunan 410013, China. ${ }^{4}$ Department of Neurosurgery, The Third Xiangya Hospital, Central South University, Changsha, Hunan 410013, China.

Received: 8 May 2017 Accepted: 14 August 2017

Published online: 25 August 2017

\section{References}

1. Thal DR, Griffin WS, de Vos RA, Ghebremedhin E. Cerebral amyloid angiopathy and its relationship to Alzheimer's disease. Acta Neuropathol. 2008;115:599-609.

2. Brenowitz WD, Nelson PT, Besser LM, Heller KB, Kukull WA. Cerebral amyloid angiopathy and its co-occurrence with Alzheimer's disease and other cerebrovascular neuropathologic changes. Neurobiol Aging. 2015;36:2702-8.

3. Kövari E, Herrmann FR, Gold G, Hof PR, Charidimou A. Association of cortical microinfarcts and cerebral small vessel pathology in the ageing brain. Neuropathol Appl Neurobiol. 2016; doi:10.1111/nan.12366.

4. Yamada M. Cerebral amyloid angiopathy: emerging concepts. J Stroke. 2015;17:17-30

5. Charidimou A, Boulouis G, Gurol ME, Ayata C, Bacskai BJ, Frosch MP, Viswanathan A, Greenberg SM. Emerging concepts in sporadic cerebral amyloid angiopathy. Brain. 2017;140:1829-50.

6. Castellani RJ, Smith MA, Perry G, Friedland RP. Cerebral amyloid angiopathy: major contributor or decorative response to Alzheimer's disease pathogenesis. Neurobiol Aging. 2004;25:599-602.

7. Greenberg SM, Vonsattel JPG. Diagnosis of cerebral amyloid angiopathy. Sensitivity and specificity of cortical biopsy. Stroke. 1997;28:1418-22.

8. Love S, Miners JS. Cerebrovascular disease in ageing and Alzheimer's disease. Acta Neuropathol. 2016;131:645-58.

9. Love S, Miners JS. Cerebral hypoperfusion and the energy deficit in Alzheimer's disease. Brain Pathol. 2016:26:607-17.

10. Pezzini A, Del Zotto E, Volonghi I, Giossi A, Costa P, Padovani A. Cerebral amyloid angiopathy: a common cause of cerebral hemorrhage. Cur Med Chem. 2009;16:2498-513.

11. Xiong $L$, Boulouis $G$, Charidimou A, Roongpiboonsopit D, Jessel MJ, Pasi M Reijmer YD, Fotiadis P, Ayres A, Merrill E, Schwab K, Blacker D, Gurol ME, Greenberg SM, Viswanathan A. Dementia incidence and predictors in cerebral amyloid angiopathy patients without intracerebral hemorrhage. J Cereb Blood Flow Metab. 2017; doi:10.1177/0271678X17700435.

12. Vidoni ED, Yeh HW, Morris JK, Newell KL, Alqahtani A, Burns NC, Burns JM, Billinger SA. Cerebral $\beta$-amyloid angiopathy is associated with earlier dementia onset in Alzheimer's disease. Neurodegener Dis. 2016;16:218-24.

13. Thal DR, Capetillo-Zarate E, Larionov S, Staufenbiel M, Zurbruegg S, Beckmann N. Capillary cerebral amyloid angiopathy is associated with vessel occlusion and cerebral blood flow disturbances. Neurobiol Aging. 2009;30:1936-48

14. Schrag M, Kirshner H. Neuropsychological effects of cerebral amyloid angiopathy. Curr Neurol Neurosci Rep. 2016;16:76.

15. Thanvi B, Robinson T. Sporadic cerebral amyloid angiopathy_an important cause of cerebral haemorrhage in older people. Age Ageing. 2006;35:565-71.

16. Herzig MC, Nostrand WE, Jucker M. Mechanism of cerebral $\beta$-amyloid angiopathy: Murine and cellular models. Brain Pathol. 2006:16:40-54

17. Reijmer YD, Fotiadis P, Martinez-Ramirez S, Salat DH, Schultz A, Shoamanesh A, Ayres AM, Vashkevich A, Rosas D, Schwab K, Leemans A, Biessels GJ, Rosand J, Johnson KA, Viswanathan A, Gurol ME, Greenberg SM. Structural network alterations and neurological dysfunction in cerebral amyloid angiopathy. Brain. 2015;138:179-88.

18. Reijmer YD, van Veluw SJ, Greenberg SM. Ischemic brain injury in cerebra amyloid angiopathy. J Cerebral Blood Flow Metab. 2016;36:40-54.
19. Pantoni L. Cerebral small vessel disease: from pathogenesis and clinical characteristics to therapeutic challenges. Lancet Neurol. 2010:9:7689-701.

20. Auriel E, Charidimou A, Gurol ME, Ni J, Van Etten ES, Martinez-Ramirez S, Boulouis G, Piazza F, DiFrancesco JC, Frosch MP, Pontes-Neto OV, Shoamanesh A, Reijmer Y, Vashkevich A, Ayres AM, Schwab KM, Viswanathan A, Greenberg SM. Validation of clinicoradiological criteria for the diagnosis of cerebral amyloid angiopathy-related inflammation. JAMA Neurol. 2016;73:197-202.

21. Charidimou A, Pantoni L, Love S. The concept of sporadic cerebral small vessel disease: a road map on key definitions and current concepts. Intl J Stroke. 2016;11:6-18.

22. likuni $\mathrm{S}$, Ono M, Watanabe H, Matsumura K, Yoshimura M, Kimura H, IshibashiUeda H, Okamoto Y, Ihara M, Saji H. Imaging of cerebral amyloid angiopathy with bivalent 99mTc-hydroxamamide complexes. Sci Rep. 2016:6:25990.

23. Cheng $X$, He P, Yao H, Dong Q, Li R, Shen Y. Occludin deficiency with BACE1 elevation in cerebral amyloid angiopathy. Neurology. 2014:82:1707-15.

24. Devraj K, Poznanovic S, Spahn C, Schwall G, Harter PN, Mittelbronn M, Antoniello K, Paganetti P, Muhs A, Heilemann M, Hawkins RA, Schrattenholz A, Liebner S. BACE-1 is expressed in the blood-brain barrier endothelium and is upregulated in a murine model of Alzheimer's disease. J Cereb Blood Flow Metab. 2016;36:1281-94.

25. Xue ZQ, He ZW, Yu JJ, Cai Y, Oiu WY, Pan A, Gai WP, Cai H, Luo XG, Ma C, Yan XX. Non-neuronal and neuronal BACE1 elevation in association with angiopathic and leptomeningeal $\beta$-amyloid deposition in the human brain. BMC Neurol. 2015;15:71

26. Beyreuther K, Dyrks T, Hilbich C, Mönning U, König G, Multhaup G, Pollwein P, Masters CL. Amyloid precursor protein (APP) and beta A4 amyloid in Alzheimer's disease and down syndrome. Prog Clin Biol Res. 1992;379:159-82.

27. Sinha S, Anderson JP, Barbour R, Basi GS, Caccavello R, Davis D, Doan M, Dovey HF, Frigon N, Hong J, Jacobson-Croak K, Jewett N, Keim P, Knops J, Lieberburg I, Power M, Tan H, Tatsuno G, Tung J, Schenk D, Seubert P, Suomensaari SM, Wang S, Walker D, Zhao J, McConlogue L, John V. Purification and cloning of amyloid precursor protein $\beta$-secretase from human brain. Nature. 1999:402:537-40.

28. Kang J, Lemaire HG, Unterbeck A, Salbaum JM, Masters CL, Grzeschik KH, Multhaup G, Beyreuther K, Müller-Hill B. The precursor of Alzheimer's disease amyloid A4 protein resembles a cell-surface receptor. Nature. 1987;325:733-6.

29. Bowen RL, Verdile G, Liu T, Parlow AF, Perry G, Smith MA, Martins RN, Atwood CS. Luteinizing hormone, a reproductive regulator that modulates the processing of amyloid- $\beta$ precursor protein and amyloid- $\beta$ deposition. J Biol Chem. 2004:279:20539-45.

30. McCarthy RC, Park YH, Kosman DJ. sAPP modulates iron efflux from brain microvascular endothelial cells by stabilizing the ferrous iron exporter ferroportin. EMBO Rep. 2014;15:809-15.

31. Turner PR, O'Connor K, Tate WP, Abraham WC. Roles of amyloid precursor protein and its fragments in regulating neural activity, plasticity and memory Prog Neurobiol. 2003;70:1-32.

32. Kamenetz F, Tomita T, Hsieh H, Seabrook G, Borchelt D, Iwatsubo T, Sisodia S, Malinow R. APP processing and synaptic function. Neuron. 2003;37:925-37.

33. Priller C, Bauer T, Mitteregger $G$, et al. Synapse formation and function is modulated by the amyloid precursor protein. J Neurosci. 2006;26:7212-21.

34. Brunholz S, Sisodia S, Lorenzo A, Deyts C, Kins S, Morfini G. Axonal transport of APP and the spatial regulation of APP cleavage and function in neuronal cells. Exp Brain Res. 2012;217:353-64.

35. Pardossi-Piquard $\mathrm{R}$, Checler $F$. The physiology of the $\beta$-amyloid precursor protein intracellular domain AICD. J Neurochem. 2012;120:109-24.

36. Chapman PF, White GL, Jones MW, Cooper-Blacketer D, Marshall VJ, Irizarry M, Younkin L, Good MA, Bliss TV, Hyman BT, Younkin SG, Hsiao KK. Impaired synaptic plasticity and learning in aged amyloid precursor protein transgenic mice. Nature Neurosci. 1999:2:271-6.

37. Milward EA, Papadopoulos R, Fuller SJ, Moir RD, Small D, Beyreuther K, Masters $\mathrm{CL}$. The amyloid protein precursor of Alzheimer's disease is a mediator of the effects of nerve growth factor on neurite outgrowth. Neuron. 1992;9:129-37.

38. Chow W, Mattson MP, Wong PC, Gleichmann M. An overview of APP processing enzymes and products. NeuroMolecular Med. 2010;12:1-12.

39. Soriano S, Lu DC, Chandra S, Pietrzik CU, Koo EH. The amyloidogenic pathway of amyloid precursor protein (APP) is independent of its cleavage by caspases. J Biol Chem. 2001;276:29045-50.

40. Zhang YW, Thompson R, Zhang H, Xu H. APP processing in Alzheimer's disease. Mol Brain. 2011:4:3

41. Siklos M, BenAissa M, Thatcher GRJ. Cysteine proteases as therapeutic targets: does selectivity matter? A systematic review of calpain and cathepsin inhibitors. Acta Pharm Sin B. 2015:5:506-19. 
42. Kumar S, Cieplak P. CaspNeuroD: a knowledgebase of predicted caspase cleavage sites in human proteins related to neurodegenerative diseases. Database (Oxford). 2016;2016(pii):baw142.

43. Schroeter EH, llagan MX, Brunkan AL, Hecimovic S, Li YM, Xu M, Lewis HD, Saxena MT, De Strooper B, Coonrod A, Tomita T, Iwatsubo T, Moore CL, Goate A, Wolfe MS, Shearman M, Kopan R. A presenilin dimer at the core of the $\gamma$-secretase enzyme: insights from parallel analysis of notch 1 and APP proteolysis. Proc Natl Acad Sci. 2003;100:13075-80.

44. Kaether $\mathrm{C}$, Haass $\mathrm{C}$, Steiner $\mathrm{H}$. Assembly, trafficking and function of $\gamma$-secretase. Neurodegener Dis. 2006;3:275-83.

45. Kimberly WT, LaVoie MJ, Ostaszewski BL, Ye W, Wolfe MS, Selkoe DJ. YSecretase is a membrane protein complex comprised of presenilin, nicastrin, aph-1, and pen-2. Proc Natl Acad Sci U S A. 2003;100:6382-7.

46. Zhang Z, Nadeau P, Song W, Donoviel D, Yuan M, Bernstein A, Yankner BA. Presenilins are required for $\gamma$-secretase cleavage of $\beta$-APP and transmembrane cleavage of notch-1. Nature Cell biol. 2000;2:463-5.

47. Li YM, Xu M, Lai MT, Huang Q, Castro JL, DiMuzio-Mower J, Harrison T, Lellis C, Nadin A, Neduvelil JG, Register RB, Sardana MK, Shearman MS, Smith AL, Shi XP, Yin KC, Shafer JA, Gardell SJ. Photoactivated $\gamma$-secretase inhibitors directed to the active site covalently label presenilin 1. Nature. 2000;405:689-94.

48. Hartmann T, Bieger SC, Brühl B, Tienari PJ, Ida N, Allsop D, Roberts GW, Masters CL, Dotti CG, Unsicker K, Beyreuther K. Distinct sites of intracellular production for Alzheimer's disease Aß40/42 amyloid peptides. Nature Med. 1997;3:1016-20

49. Willem M, Tahirovic S, Busche MA, Ovsepian SV, Chafai M, Kootar S, Hornburg D, Evans LD, Moore S, Daria A, Hampel H, Müller V, Giudici C, Nuscher B, Wenninger-Weinzierl A, Kremmer E, Heneka MT, Thal DR, Giedraitis V, Lannfelt L, Müller U, Livesey FJ, Meissner F, Herms J, Konnerth A, Marie H, Haass C. nSecretase processing of APP inhibits neuronal activity in the hippocampus. Nature. 2015:526:443-7.

50. Deane R, Bell RD, Sagare A, Zlokovic BV. Clearance of amyloid- $\beta$ peptide across the blood-brain barrier: implication for therapies in Alzheimer's disease. CNS Neurol Disord Drug Targets. 2009;8:16-30.

51. Lee CYD, Landreth GE. The role of microglia in amyloid clearance from the AD brain. J Neural Transmission. 2010;117:949-60.

52. Wildsmith KR, Holley M, Savage JC, Skerrett R, Landreth GE. Evidence for impaired amyloid $\beta$ clearance in Alzheimer's disease. Alzheimers Res Ther. 2013;5:33.

53. Bakker EN, Bacskai BJ, Arbel-Ornath M, Aldea R, Bedussi B, Morris AW, Weller RO, Carare RO. Lymphatic clearance of the brain: Perivascular, Paravascular and significance for neurodegenerative diseases. Cell Mol Neurobiol. 2016; 36:181-94.

54. Vassar R, Kovacs DM, Yan R, Wong PC. The $\beta$-secretase enzyme BACE in health and Alzheimer's disease: regulation, cell biology, function, and therapeutic potential. J Neurosci. 2009;29:12787-94.

55. Yan XX, Ma C, Gai WP, Cai H, Luo XG. Can BACE1 inhibition mitigate early axonal pathology in neurological diseases? J Alzheimers Dis. 2014;38:705-18.

56. Card JP, Meade RP, Davis LG. Immunocytochemical localization of the precursor protein for $\beta$-amyloid in the rat central nervous system. Neuron. 1988;1:835-46.

57. Kim KS, Wegiel J, Sapienza V, Chen J, Hong H, Wisniewski HM. Immunoreactivity of presenilin-1 in human, rat and mouse brain. Brain Res. 1997;757:159-63.

58. Yan XX, Li T, Rominger CM, Prakash SR, Wong PC, Olson RE, Zaczek R, Li YW. Binding sites of $\gamma$-secretase inhibitors in rodent brain: distribution, postnatal development, and effect of deafferentation. J Neurosci. 2004;24:2942-52.

59. Leuba G, Wernli G, Vernay A, Kraftsik R, Mohajeri MH, Saini KD. Neuronal and nonneuronal quantitative BACE immunocytochemical expression in the entorhinohippocampal and frontal regions in Alzheimer's disease. Dement Geriatr Cogn Disord. 2005;19:171-83.

60. Laird FM, Cai H, Savonenko AV, Farah MH, He K, Melnikova T, Wen H, Chiang HC, Xu G, Koliatsos VE, Borchelt DR, Price DL, Lee HK, Wong PC. BACE1, a major determinant of selective vulnerability of the brain to amyloid- $\beta$ amyloidogenesis, is essential for cognitive, emotional, and synaptic functions. J Neurosci. 2005;25: 11693-709.

61. Yan XX, Xiong K, Luo XG, Struble RG, Clough RW. Beta-Secretase expression in normal and functionally deprived rat olfactory bulbs: inverse correlation with oxidative metabolic activity. J Comp Neurol. 2007;501:52-69.

62. Zhang XM, Cai Y, Xiong K, Cai H, Luo XG, Feng JC, Clough RW, Struble RG, Patrylo PR, Yan XX. Beta-Secretase-1 elevation in transgenic mouse models of Alzheimer's disease is associated with synaptic/axonal pathology and amyloidogenesis: implications for neuritic plaque development. Eur J Neurosci. 2009;30:2271-83.
63. Rajapaksha TW, Eimer WA, Bozza TC, Vassar R. The Alzheimer's $\beta$-secretase enzyme BACE1 is required for accurate axon guidance of olfactory sensory neurons and normal glomerulus formation in the olfactory bulb. Mol Neurodegener. 2011;6:88.

64. Cao L, Rickenbacher GT, Rodriguez S, Moulia TW, Albers MW. The precision of axon targeting of mouse olfactory sensory neurons requires the BACE1 protease. Sci Rep. 2012;2:231

65. Sheng JG, Price DL, Koliatsos VE. The $\beta$-amyloid-related proteins presenilin 1 and BACE1 are axonally transported to nerve terminals in the brain. Exp Neurol. 2003;184:1053-7.

66. Kandalepas PC, Sadleir KR, Eimer WA, Zhao J, Nicholson DA, Vassar R. The Alzheimer's $\beta$-secretase BACE1 localizes to normal presynaptic terminals and to dystrophic presynaptic terminals surrounding amyloid plaques. Acta Neuropathol. 2013;126:329-52.

67. Buggia-Prévot $V$, Fernandez CG, Riordan S, Vetrivel KS, Roseman J, Waters J, Bindokas VP, Vassar R, Thinakaran G. Axonal BACE1 dynamics and targeting in hippocampal neurons: a role for Rab11 GTPase. Mol Neurodegener. 2014;9:1

68. Del Prete D, Lombino F, Liu X, D'Adamio L. APP is cleaved by Bace1 in presynaptic vesicles and establishes a pre-synaptic interactome, via its intracellular domain, with molecular complexes that regulate pre-synaptic vesicles functions. PLoS One. 2014;9:e108576

69. Lundgren JL, Ahmed S, Schedin-Weiss S, Gouras GK, Winblad B, Tjernberg LO, Frykman S. ADAM10 and BACE1 are localized to synaptic vesicles. J Neurochem. 2015;135:606-15.

70. Pliássova A, Lopes JP, Lemos C, Oliveira CR, Cunha RA, Agostinho P. The association of amyloid- $\beta$ protein precursor with $\alpha$-and $\beta$-secretases in mouse cerebral cortex synapses is altered in early Alzheimer's disease. Mol Neurobiol. 2016;53:5710-21.

71. Ye X, Feng T, Tammineni P, Chang Q, Jeong YY, Margolis DJ, Cai H, Kusnecov A, Cai $Q$. Regulation of synaptic amyloid- $\beta$ generation through BACE1 retrograde transport in a mouse model of Alzheimer's disease. J Neurosci. 2017;37:2639-55.

72. Kitazume S, Tachida Y, Kato M, Yamaguchi Y, Honda T, Hashimoto Y, Wada $Y$, Saito T, Iwata N, Saido T, Taniguchi N. Brain endothelial cells produce amyloid $\beta$ from amyloid precursor protein 770 and preferentially secrete the O-glycosylated form. J Biol Chem. 2010;285:40097-400103.

73. Simons ER, Marshall DC, Long HJ, Otto K, Billingslea A, Tibbles H, Wells J, Eisenhauer $\mathrm{P}$, Fine RE, Cribbs DH, Davies TA, Abraham CR. Blood brain barrier endothelial cells express candidate amyloid precursor protein-cleaving secretases. Amyloid. 1998:5:153-62.

74. Austin SA, Santhanam AV, Katusic ZS. Endothelial nitric oxide modulates expression and processing of amyloid precursor protein. Circ Res. 2010;107:1498-502.

75. Ma JF, Wang HM, Li QY, Zhang Y, Pan J, Qiang Q, Xin XY, Tang HD, Ding JQ, Chen SD. Starvation triggers Aß42 generation from human umbilical vascular endothelial cells. FEBS Lett. 2010;584:3101-6.

76. Bulbarelli A, Lonati E, Brambilla A, Orlando A, Cazzaniga E, Piazza F, Ferrarese C, Masserini M, Sancini G. A 42 production in brain capillary endothelial cells after oxygen and glucose deprivation. Mol Cell Neurosci. 2012;49:415-22.

77. Deng X, Zhang J, Liu Y, Chen L, Yu C. TNF-a regulates the proteolytic degradation of ST6Gal-1 and endothelial cell-cell junctions through upregulating expression of BACE1. Sci Rep. 2017;7:40256.

78. Coma M, Guix FX, II-Raga G, Uribesalgo I, Alameda F, Valverde MA, Muñoz FJ. Oxidative stress triggers the amyloidogenic pathway in human vascular smooth muscle cells. Neurobiol Aging. 2008;29:969-80.

79. Frackowiak J, Potempska A, Mazur-Kolecka B. Formation of amyloid- $\beta$ oligomers in brain vascular smooth muscle cells transiently exposed to iron-induced oxidative stress. Acta Neuropathol. 2009:117:557-67.

80. Cai $Y$, Xiong K, Zhang XM, Cai H, Luo XG, Feng JC, Clough RW, Struble RG, Patrylo PR, Chu Y, Kordower JH, Yan XX. $\beta$-Secretase-1 elevation in aged monkey and Alzheimer's disease human cerebral cortex occurs around the vasculature in partnership with multisystem axon terminal pathogenesis and $\beta$-amyloid accumulation. Eur J Neurosci. 2010;32:1223-38.

81. Tokuda T, Ikeda S, Maruyama K, Yanagisawa N, Ito N. Spinal cord vascular and leptomeningeal amyloid $\beta$-protein deposition in a case with cerebral amyloid angiopathy. Acta Neuropathol. 1992;84:207-10.

82. Galasko D. Searching for Neurodegeneration in the blood of patients with Alzheimer disease. JAMA Neurol. 2017;74:510-1.

83. Mendel T, Wierzba-Bobrowicz T, Stępień T, Szpak GM. $\beta$-amyloid deposits in veins in patients with cerebral amyloid angiopathy and intracerebral haemorrhage. Folia Neuropathol. 2013;51:120-6.

84. Thal DR, Ghebremedhin E, Rüb U, Yamaguchi H, Del Tredici K, Braak H. Two types of sporadic cerebral amyloid angiopathy. J Neuropathol Exp Neurol. 2002;61:282-93. 
85. Thal DR, Rüb U, Orantes M, Braak H. Phases of A $\beta$-deposition in the human brain and its relevance for the development of AD. Neurology. 2002;58: 1791-800.

86. Mendel TA, Wierzba-Bobrowicz T, Lewandowska E, Stępień T, Szpak GM. The development of cerebral amyloid angiopathy in cerebral vessels. A review with illustrations based upon own investigated post mortem cases. Pol J Pathol. 2013;64:260-7.

87. Attems J. Sporadic cerebral amyloid angiopathy: pathology, clinical implications, and possible pathomechanisms. Acta Neuropathol. 2005;110:345-59.

88. Oshima K, Uchikado H, Dickson DW. Perivascular neuritic dystrophy associated with cerebral amyloid angiopathy in Alzheimer's disease. Int J Clin Exp Pathol. 2008;1:403-8.

89. Richard E, Carrano A, Hoozemans JJ, van Horssen J, van Haastert ES, Eurelings LS, de Vries HE, Thal DR, Eikelenboom P, van Gool WA, Rozemuller AJ. Characteristics of dyshoric capillary cerebral amyloid angiopathy. J Neuropathol Exp Neurol. 2010;69:1158-67.

90. Hardy JA, Gerald HA. Alzheimer's disease: the amyloid cascade hypothesis. Science. 1992;256:5054.

91. Pflanzner TR, Kuhlmann CU, Pietrzik C. Blood-brain-barrier models for the investigation of transporter-and receptor-mediated amyloid- $\beta$ clearance in Alzheimer's disease. Curr Alzheimer Res. 2010;7:578-90.

92. Silverberg GD, Messier AA, Miller MC, Machan JT, Majmudar SS, Stopa EG, Donahue JE, Johanson CE. Amyloid efflux transporter expression at the blood-brain barrier declines in normal aging. J Neuropathol Exp Neurol. 2010;69:1034-43

93. Pascale CL, Miller MC, Chiu C, Boylan M, Caralopoulos IN, Gonzalez L, Johanson CE, Silverberg GD. Amyloid-beta transporter expression at the blood-CSF barrier is age-dependent. Fluids Barriers CNS. 2011:8:21.

94. Zhang $Y$, Lee DHS. Sink hypothesis and therapeutic strategies for attenuating A $\beta$ levels. Neuroscientist. 2011;17:163-73.

95. Padovani A, Pastorino L, Borroni B, Colciaghi F, Rozzini L, Monastero R, Perez J, Pettenati C, Mussi M, Parrinello G, Cottini E, Lenzi GL, Trabucchi M, Cattabeni F, Di Luca M. Amyloid precursor protein in platelets: a peripheral marker for the diagnosis of sporadic AD. Neurology. 2001;57:2243-8.

96. Casoli T, Di Stefano G, Giorgetti B, Grossi Y, Balietti M, Fattoretti P, BertoniFreddari $\mathrm{C}$. Release of beta-amyloid from high-density platelets: implications for Alzheimer's disease pathology. Ann N Y Acad Sci. 2007;1096:170-8.

97. Jelic V, Hagman G, Yamamoto NG, Teranishi Y, Nishimura T, Winblad B, Pavlov PF. Abnormal platelet amyloid- $\beta$ protein precursor (A $\beta P P)$ metabolism in Alzheimer's disease: identification and characterization of a new AßPP isoform as potential biomarker. J Alzheimers Dis. 2013;35:285-95.

98. Henderson SJ, Andersson C, Narwal R, Janson J, Goldschmidt TJ, Appelkvist P, Bogstedt A, Steffen AC, Haupts U, Tebbe J, Freskgård PO, Jermutus L, Burrell M, Fowler SB, Webster Cl. Sustained peripheral depletion of amyloid$\beta$ with a novel form of neprilysin does not affect central levels of amyloid- $\beta$. Brain. 2014;137:553-64.

99. Georgievska B, Gustavsson S, Lundkvist J, Neelissen J, Eketjäll S, Ramberg V, Bueters T, Agerman K, Juréus A, Svensson S, Berg S, Fälting J, Lendahl U. Revisiting the peripheral sink hypothesis: inhibiting BACE1 activity in the periphery does not alter $\beta$-amyloid levels in the CNS. J Neurochem. 2015; 132:477-86.

100. Stone JA, Parker E. Is the peripheral sink hypothesis physiologically feasible? Evidence from model-based assessment of the amyloid pathway. Alzheimer's Dis Dem. 2016;12:443.

101. Kuperstein I, Broersen K, Benilova I, Rozenski J, Jonckheere W, Debulpaep M, Vandersteen A, Segers-Nolten I, Van Der Werf K, Subramaniam V, Braeken D, Callewaert G, Bartic C, D'Hooge R, Martins IC, Rousseau F, Schymkowitz J, De Strooper B. Neurotoxicity of Alzheimer's disease A $\beta$ peptides is induced by small changes in the $A \beta 42$ to $A \beta 40$ ratio. EMBO J. 2010;29:3408-20.

102. Schoonenboom NS, Mulder C, Van Kamp GJ, Mehta SP, Scheltens P, Blankenstein MA, Mehta PD. Amyloid beta 38, 40, and 42 species in cerebrospinal fluid: more of the same? Ann Neurol. 2005;58:139-42.

103. Beaufils E, Dufour-Rainfray D, Hommet C, Brault F, Cottier JP, Ribeiro MJ, Mondon $K$, Guilloteau D. Confirmation of the amyloidogenic process in posterior cortical atrophy: value of the Aß42/A 340 ratio. J Alzheimers Dis. 2013;33:775-80.

104. Kayed R, Lasagna-Reeves CA. Molecular mechanisms of amyloid oligomers toxicity. J Alzheimers Dis. 2013;33:S67-78.

105. Frost B, Diamond MI. Prion-like mechanisms in neurodegenerative diseases. Nat Rev Neurosci. 2010;11:155-9.

106. Polymenidou M, Cleveland DW. Prion-like spread of protein aggregates in neurodegeneration. J Exp Med. 2012;209:889-93.
107. Stopschinski BE, Diamond MI. The prion model for progression and diversity of neurodegenerative diseases. Lancet Neurol. 2017;16:323-32.

108. Fukumoto $\mathrm{H}$, Cheung BS, Hyman BT, Irizarry MC. Beta-secretase protein and activity are increased in the neocortex in Alzheimer disease. Arch Neurol. 2002;59:1381-9.

109. Holsinger RM, McLean CA, Beyreuther K, Masters CL, Evin G. Increased expression of the amyloid precursor beta-secretase in Alzheimer's disease. Ann Neurol. 2002;51:783-6.

110. Li R, Lindholm K, Yang LB, Yue X, Citron M, Yan R, Beach T, Sue L, Sabbagh $M$, Cai $H$, Wong P, Price $D$, Shen Y. Amyloid beta peptide load is correlated with increased beta-secretase activity in sporadic Alzheimer's disease patients. Proc Natl Acad Sci U S A. 2004;101:3632-7.

111. Yang LB, Lindholm $K$, Yan R, Citron M, Xia W, Yang XL, Beach T, Sue L, Wong P, Price D, Li R, Shen Y. Elevated beta-secretase expression and enzymatic activity detected in sporadic Alzheimer disease. Nat Med. 2003:9:3-4.

112. Miners JS, van Helmond Z, Kehoe PG, Love S. Changes with age in the activities of beta-secretase and the Abeta-degrading enzymes neprilysin, insulin-degrading enzyme and angiotensin-converting enzyme. Brain Pathol. 2010;20:794-802.

113. Zhao J, Fu Y, Yasvoina M, Shao P, Hitt B, O'Connor T, Logan S, Maus E, Citron M, Berry R, Binder L, Vassar R. $\beta$-site amyloid precursor protein cleaving enzyme 1 levels become elevated in neurons around amyloid plaques: implications for Alzheimer's disease pathogenesis. J Neurosci. 2007;27:3639-49.

114. Sanchez-Varo R, Trujillo-Estrada L, Sanchez-Mejias E, Torres M, BagliettoVargas D, Moreno-Gonzalez I, De Castro V, Jimenez S, Ruano D, Vizuete M, Davila JC, Garcia-Verdugo JM, Jimenez AJ, Vitorica J, Gutierrez A. Abnormal accumulation of autophagic vesicles correlates with axonal and synaptic pathology in young Alzheimer's mice hippocampus. Acta Neuropathol. 2012;123:53-70.

115. Li JM, Xue ZQ, Deng SH, Luo XG, Patrylo PR, Rose GW, Cai H, Cai Y, Yan XX. Amyloid plaque pathogenesis in 5XFAD mouse spinal cord: retrograde transneuronal modulation after peripheral nerve injury. Neurotox Res. 2013;24:1-14

116. Sadleir KR, Kandalepas PC, Buggia-Prévot V, Nicholson DA, Thinakaran G Vassar R. Presynaptic dystrophic neurites surrounding amyloid plaques are sites of microtubule disruption, BACE1 elevation, and increased $A \beta$ generation in Alzheimer's disease. Acta Neuropathol. 2016;132:235-56.

117. MacKenzie JM. Examining the decomposed brain. Am J Forensic Med Pathol. 2014;35:265-70.

118. Omalu BI, Mancuso JA, Cho P, Wecht CH. Diagnosis of Alzheimer's disease in an exhumed decomposed brain after twenty months of burial in a deep grave. J Forensic Sci. 2005;50:1453-8.

119. Gelpi E, Preusser M, Bauer G, Budka H. Autopsy at 2 months after death: brain is satisfactorily preserved for neuropathology. Forensic Sci Int. 2007; 168:177-82.

120. Blazquez-Llorca L, Valero-Freitag S, Rodrigues EF, Merchán-Pérez Á, Rodríguez JR, Dorostkar MM, DeFelipe J, Herms J. High plasticity of axonal pathology in Alzheimer's disease mouse models. Acta Neuropathol Commun. 2017;5:14.

121. Adalbert R, Nogradi A, Babetto E, Janeckova L, Walker SA, Kerschensteiner M, Misgeld T, Coleman MP. Severely dystrophic axons at amyloid plaques remain continuous and connected to viable cell bodies. Brain. 2009;132: 402-16

122. Dickson TC, Vickers JC. The morphological phenotype of $\beta$-amyloid plaques and associated neuritic changes in Alzheimer's disease. Neurosci. 2001;105:99-107.

123. Duyckaerts C, Delatour B, Potier MC. Classification and basic pathology of Alzheimer disease. Acta Neuropathol. 2009;118:5-36.

124. Campbell MJ, Lewis DA, Foote SL, Morrison JH. Distribution of choline acetyltransferase-, serotonin-, dopamine-beta-hydroxylase-, tyrosine hydroxylaseimmunoreactive fibers in monkey primary auditory cortex. J Comp Neurol. 1987; 261:209-20.

125. Berger B, Gaspar P, Verney C. Dopaminergic innervation of the cerebral cortex: unexpected differences between rodents and primates. Trends Neurosci. 1991; 14:21-7.

126. Cai Y, Zhang XM, Macklin LN, Cai H, Luo XG, Oddo S, Laferla FM, Struble RG, Rose GM, Patrylo PR, Yan XX. BACE1 elevation is involved in amyloid plaque development in the triple transgenic model of Alzheimer's disease: differential $A \beta$ antibody labeling of early-onset axonal terminal pathology. Neurotox Res. 2012;21:160-74.

127. Chen XH, Siman R, Iwata A, Meaney DF, Trojanowski JQ, Smith DH. Long-term accumulation of amyloid-beta, beta-secretase, presenilin-1, and caspase-3 in damaged axons following brain trauma. Am J Pathol. 2004;165:357-71. 
128. Yu F, Zhang Y, Chuang DM. Lithium reduces BACE1 overexpression, beta amyloid accumulation, and spatial learning deficits in mice with traumatic brain injury. J Neurotrauma. 2012;29:2342-51.

129. Pajoohesh-Ganji A, Burns MP, Pal-Ghosh S, Tadvalkar G, Hokenbury NG, Stepp MA, Faden Al. Inhibition of amyloid precursor protein secretases reduces recovery after spinal cord injury. Brain Res. 2014;1560:73-82.

130. Daneshvar DH, Goldstein LE, Kiernan PT, Stein TD, McKee AC. Post-traumatic neurodegeneration and chronic traumatic encephalopathy. Mol Cell Neurosci. 2015;66:81-90

131. Li JM, Cai Y, Liu F, Yang L, Hu X, Patrylo PR, Cai H, Luo XG, Xiao D, Yan XX. Experimental microembolism induces localized neuritic pathology in guinea pig cerebrum. Oncotarget. 2015;6:10772.

132. Yan XX, Cai Y, Zhang XM, Luo XG, Cai H, Rose GM, Patrylo PR. BACE1 elevation is associated with aberrant limbic axonal sprouting in epileptic CD1 mice. Exp Neurol. 2012;235:228-37.

133. Deng X, Li M, Ai W, He L, Lu D, Patrylo PR, Cai H, Luo X, Li Z, Yan X. Lipolysaccharide-induced neuroinflammation is associated with Alzheimer-like amyloidogenic axonal pathology and dendritic degeneration in rats. Adv Alzheimer Dis. 2014;3:78-93.

134. Tajiri N, Kellogg SL, Shimizu T, Arendash GW, Borlongan CV. Traumatic brain injury precipitates cognitive impairment and extracellular $A \beta$ aggregation in Alzheimer's disease transgenic mice. PLoS One. 2013;8:e78851.

135. Yan XX, Cai Y, Shelton J, Deng SH, Luo XG, Oddo S, Laferla FM, Cai H, Rose GM, Patrylo PR. Chronic temporal lobe epilepsy is associated with enhanced Alzheimer-like neuropathology in 3x Tg-AD mice. PLoS One. 2012;7:e48782.

136. Collins JM, King AE, Woodhouse A, Kirkcaldie MT, Vickers JC. The effect of focal brain injury on beta-amyloid plaque deposition, inflammation and synapses in the APP/PS1 mouse model of Alzheimer's disease. Exp Neurol. 2015;267:219-29.

137. Yan XX, Jen LS, Garey LJ. NADPH-diaphorase-positive neurons in primate cerebral cortex colocalize with GABA and calcium-binding proteins. Cereb Cortex. 1996;6:524-9.

138. Anstey KJ, Lipnicki DM, Low LF. Cholesterol as a risk factor for dementia and cognitive decline: a systematic review of prospective studies with meta-analysis. Am J Geriatr Psychiatry. 2008;16:343-54.

139. Solomon A, Kivipelto M, Wolozin B, Zhou J, Whitmer RA. Midlife serum cholesterol and increased risk of Alzheimer's and vascular dementia three decades later. Dement Geriatr Cogn Disord. 2009;28:75-80.

140. Tolppanen AM, Solomon A, Soininen H, Kivipelto M. Midlife vascular risk factors and Alzheimer's disease: evidence from epidemiological studies. J Alzheimers Dis. 2012;32:531-40.

141. Reed B, Villeneuve S, Mack W, DeCarli C, Chui HC, Jagust W. Associations between serum cholesterol levels and cerebral amyloidosis. JAMA Neurol. 2014;71:195-200.

142. Baumgart M, Snyder HM, Carrillo MC, Fazio S, Kim H, Johns H. Summary of the evidence on modifiable risk factors for cognitive decline and dementia: a population-based perspective. Alzheimers Dement. 2015;11:718-26.

143. Safouris A, Psaltopoulou T, Sergentanis TN, Boutati E, Kapaki E, Tsivgoulis G. Vascular risk factors and Alzheimer's disease pathogenesis: are conventional pharmacological approaches protective for cognitive decline progression? CNS Neurol Disord Drug Targets. 2015;14:257-69.

144. Huang G, Xue Z, Hu X, Wan LL, Li J, Cai Y, Patrylo PR, Luo XG, Pan A, Yan $X X$. Cholesterol potentiates $\beta$-amyloid genesis in cultured human umbilical vein endothelial cells. Adv Alzheimer's Dis. 2016;5:23-34.

145. Salloway S, Sperling R, Fox NC, Blennow K, Klunk W, Raskind M, Sabbagh M, Honig LS, Porsteinsson AP, Ferris S, Reichert M, Ketter N, Nejadnik B, Guenzler V, Miloslavsky M, Wang D, Lu Y, Lull J, Tudor IC, Liu E, Grundman M, Yuen E, Black R, Brashear HR, Bapineuzumab 301 and 302 Clinical Trial Investigators. Two phase 3 trials of bapineuzumab in mild-to-moderate Alzheimer's disease. N Engl J Med. 2014;370:322-33.

146. Castello MA, Jeppson JD, Soriano S. Moving beyond anti-amyloid therapy for the prevention and treatment of Alzheimer's disease. BMC Neurol. 2014;14:169.

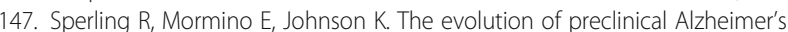
disease: implications for prevention trials. Neuron. 2014;84:608-22.

148. Barão S, Moechars D, Lichtenthaler SF, De Strooper B. BACE1 physiological functions may limit its use as therapeutic target for Alzheimer's disease. Trends Neurosci. 2016;39:158-69.

149. Gu T, Wu WY, Dong ZX, Yu SP, Sun Y, Zhong Y, Lu YT, Li NG. Development and structural modification of BACE1 inhibitors. Molecules. 2016;22:4.
150. Ohno M. Alzheimer's therapy targeting the $\beta$-secretase enzyme BACE1: benefits and potential limitations from the perspective of animal model studies. Brain Res Bull. 2016;126:183-98.

151. Yan R, Vassar R. Targeting the $\beta$ secretase BACE1 for Alzheimer's disease therapy. Lancet Neurol. 2014;13:319-29.

152. Yan R. Physiological functions of the $\beta$-site amyloid precursor protein cleaving enzyme 1 and 2. Front Mol Neurosci. 2017;10:97.

153. Hitt BD, Jaramillo TC, Chetkovich DM, Vassar R. BACE1-/-mice exhibit seizure activity that does not correlate with sodium channel level or axonal localization. Mol Neurodegener. 2010;5:31.

154. Willem M, Garratt AN, Novak B, Citron M, Kaufmann S, Rittger A, DeStrooper $B$, Saftig P, Birchmeier C, Haass C. Control of peripheral nerve myelination by the beta-secretase BACE1. Science. 2006;314:664-6.

155. Filser S, Ovsepian SV, Masana M, Blazquez-Llorca L, Brandt Elvang A, Volbracht C, Müller MB, Jung CK, Herms J. Pharmacological inhibition of BACE1 impairs synaptic plasticity and cognitive functions. Biol Psychiatry. 2015;77:729-39.

156. Miyakawa T, Shimoji A, Kuramoto $R$, Higuchi $Y$. The relationship between senile plaques and cerebral blood vessels in Alzheimer's disease and senile dementia. Morphological mechanism of senile plaque production. Virchows Arch B Cell Pathol Mol Pathol. 1982;40:121-9.

157. Kawai M, Kalaria RN, Harik SI, Perry G. The relationship of amyloid plaques to cerebral capillaries in Alzheimer's disease. Am J Pathol. 1990;137:1435-46.

158. Kawai M, Cras P, Perry G. Serial reconstruction of beta-protein amyloid plaques: relationship to microvessels and size distribution. Brain Res. 1992; 592:278-82.

159. Erickson MA, Banks WA. Blood-brain barrier dysfunction as a cause and consequence of Alzheimer's disease. J Cereb Blood Flow Metab. 2013;33: 1500-13.

160. de la Torre JC. Alzheimer's disease is a vasocognopathy: a new term to describe its nature. Neurol Res. 2004;26:517-24.

161. Stone J, Johnstone D, Mitrofanis J, O'Rourke M. The mechanical cause of age-related dementia: the brain is destroyed by the pulse. J Alz Dis. 2015;44: $355-73$.

162. Hu X, Hu ZL, Li Z, Ruan CS, Qiu WY, Pan A, Li CQ, Cai Y, Shen L, Chu Y, Tang BS, Cai H, Zhou XF, Ma C, Yan XX. Sortilin ffragments deposit at senile plaques in human cerebrum. Front Neuroanat. 2017;11:45.

163. Coria F, Castano E, Prelli F, Larrondo-Lillo M, van Duinen S, Shelanski ML, Frangione B. Isolation and characterization of amyloid P component from Alzheimer's disease and other types of cerebral amyloidosis. Lab Investig. 1988;58:454-8

164. Watson MD, Roher AE, Kim KS, Spiegel K, Emmerling M. Complement interactions with amyloid Abeta 1-42: a nidus for inflammation in AD brains. Amyloid: Int J Exp Clin Invest. 1997:4:147-56.

165. Wu CW, Liao PC, Yu L, Wang ST, Chen ST, Wu M, Ku YM. Hemoglobin promotes $A \beta$ oligomer formation and localizes in neurons and amyloid deposits. Neurobiol Dis. 2004;17:367-77.

\section{Submit your next manuscript to BioMed Central and we will help you at every step:}

- We accept pre-submission inquiries

- Our selector tool helps you to find the most relevant journal

- We provide round the clock customer support

- Convenient online submission

- Thorough peer review

- Inclusion in PubMed and all major indexing services

- Maximum visibility for your research

Submit your manuscript at www.biomedcentral.com/submit 